Apidologie, 1985, 16 (4), 421-436

\title{
THE INFLUENCE OF THE MITE VARROA JACOBSONI OUD. ON THE PROTEIN CONCENTRATION AND THE HAEMOLYMPH VOLUME OF THE BROOD OF WORKER BEES AND DRONES OF THE HONEY BEE APIS MELLIFERA L.
}

\author{
K.P. WEINBERG, G. MADEL \\ Institut für Angewandte Zoologie, An der Immenburg 1, 5300 Bonn I
}

\section{SUMMARY}

Protein concentrations in the haemolymph of non-infected and varroa-infected worker and drone brood were examined by a photometric method. The determination of the haemolymph volume was carried out by the $[14 \mathrm{C}]-$ inulin-dilution-method. The results of these two measurements were used to calculate the total protein content in the haemolymph of the worker and drone pupae (brown eyes). The findings showed that the worker and the drone brood react differently to varroa infestation.

1. The protein concentration in the haemolymph of the worker brood decreased; however it increased in the drone brood in relation to the intensity of parasitization (mites/cell).

2. In both castes, haemolymph volume was reduced in relation to increasing numbers of mites. The reduction of haemolymph volume in drone pupae was less than in worker pupae.

3. The total protein content of worker pupae decreased rapidly after varroa infestation and was related to the number of mites. This correlation does not exist in the drone pupae although there was a noticeable reduction in the total protein content.

\section{INTRODUCTION}

With the exception of North America and Australia, varroatosis is spread throughout all the continents. Consequently many scientists in different countries have been busy studying the plague. In the early stages of the research there was one question in the foreground «how to combat this plague». After a short period of time, the emphasis changed to intensive investigations concerning the biology of this mite, in particular the interaction between the host (bee) and the parasite (mite). Comprehensive knowledge about these interactions will lead to alternatives to the present chemical control methods. This research deals with one aspect of the interactions between host and parasite. 


\section{MATERIALS AND METHODS}

The major part of the Apis mellifera carnica was taken from the bee hives of our institute (a small part was taken from the Institut für Landwirtschaftliche Zoologie, Abtl. Bienenkunde, Bonn). Three groups of brood from both castes representing different ages were examined : pupae with white eyes, pupae with brown eyes in the early stages of pigmentation, and third, pre-emerging bees. These three groups were then further differentiated by the intensity of parasitization (number of haemolymph-sucking mites per cell).

The haemolymph was obtained by pricking the region of the neck (between the head and the thorax) and collected by means of a micro-capillar tube. In order to avoid individual differences it became necessary to mix the haemolymph from 2-3 bees into one sample.

The determination of the protein concentration was carried out using LOWRY's method. The $[14 \mathrm{C}]$ - inulin-dilution-method was employed in the determination of the haemolymph volumes (L. LeVENBooK, 1958). [14C]-inulin was injected into the thorax because it was discovered that an injection into the soft abdomen led to a simultaneous release of haemolymph. The incubation time lasted 1-2 hours for the workers bees and 3-4 hours for the drones. The results were statistically confirmed by the student's t-test.

\section{RESULTS}

Symbols used :

$\mathrm{n} \quad$ : number of samples.

$\tilde{\mathrm{X}} \quad$ : average values of the samples.

$\mathrm{s}_{\mathbf{x}} \quad$ : standard deviation.

$\%$ : percent deviation of the average values of the samples from the control group.

$\mathrm{P} \quad$ : significantly different by t-test at $\mathrm{P}<5$.

C : control group.

w.e. : pupae with white eyes.

b.e. : pupae with brown eyes.

h.b. : pupae in the pre-emerging stage.

\section{Protein concentration in the haemolymph of worker brood}

The three categories : pupae with white eyes, pupae with brown eyes and bees in the pre-emerging stage, were classified according to the intensity of parasitization into the following groups : bees with 1-3 mites, 4-6 mites, and bees without mites (control).

The results are summarized in tabl. 1. 
All the average protein concentrations in the haemolymph of the investigated brood stages showed a continuous decrease with an increasing number of mites.

Fig. 1 shows the average haemolymph protein concentration of $63.32 \mu \mathrm{g} / \mu 1$ in unparasitized worker pupae with white eyes. This concentration was diminished by $3.77 \%$ to $60.93 \mu \mathrm{g} / \mu \mathrm{l}$ at an infestation rate of $1-3 \mathrm{mites} / \mathrm{cell}$.

The protein concentration of pupae with brown eyes $\left(x_{c}=27.00 \mu \mathrm{g} / \mu \mathrm{l}\right)$ was reduced by $4.78 \%$ to $25.71 \mu \mathrm{g} / \mu \mathrm{l}$ and by $16.67 \%$ to $22.50 \mu \mathrm{g} / \mu \mathrm{l}$ for 1-3 mites and 4-6 mites respectively (Fig. 2).

Corresponding results were obtained from bees in the pre-emerging stage (Fig. 3). In comparison to the control group $\left(x_{c}=16.35 \mu \mathrm{g} / \mu \mathrm{l}\right)$ the concentrations at a parasitization rate of $1-3$ mites decreased by $6.24 \%(15.33 \mu \mathrm{g} / \mu \mathrm{l})$ and with $4-6$ mites by $11.19 \%(14.52 \mu \mathrm{g} / \mu \mathrm{l})$.

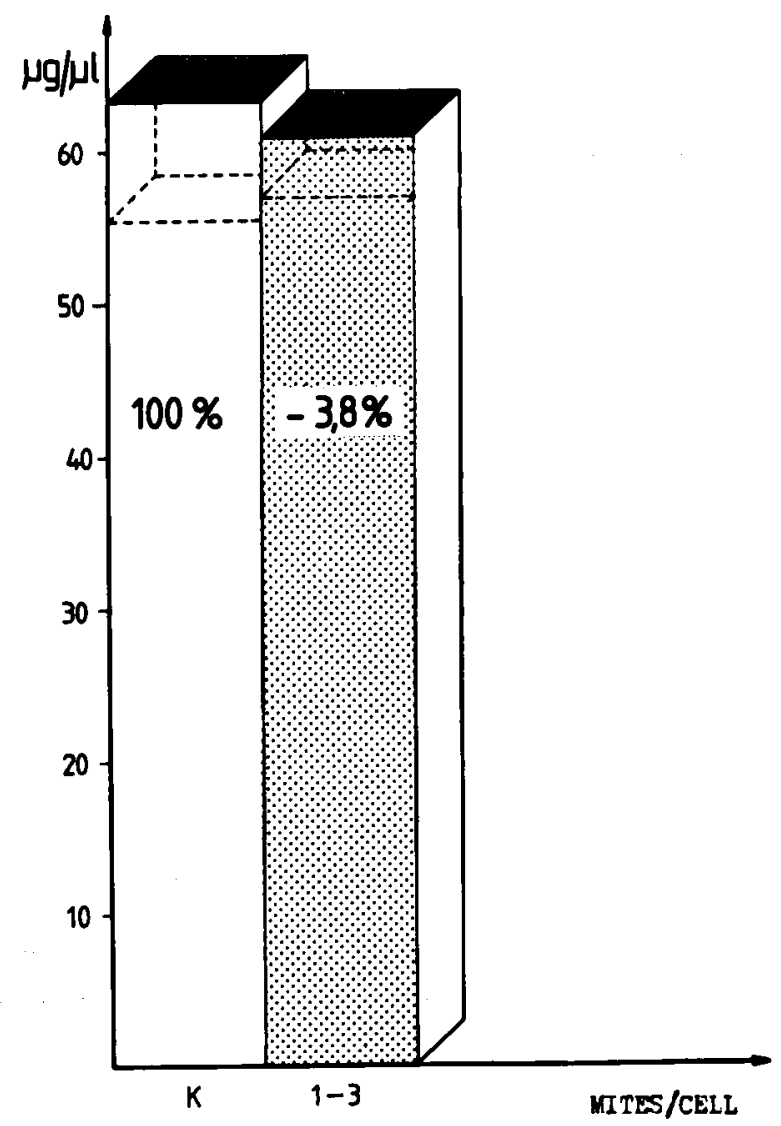

FIG. 1. - Protein concentration in the haemolymph $(\mu \mathrm{g} / \mu \mathrm{l})$ of worker pupae with white eyes in relation to the infestation rate

Dotted lines $=$ standard deviation. 


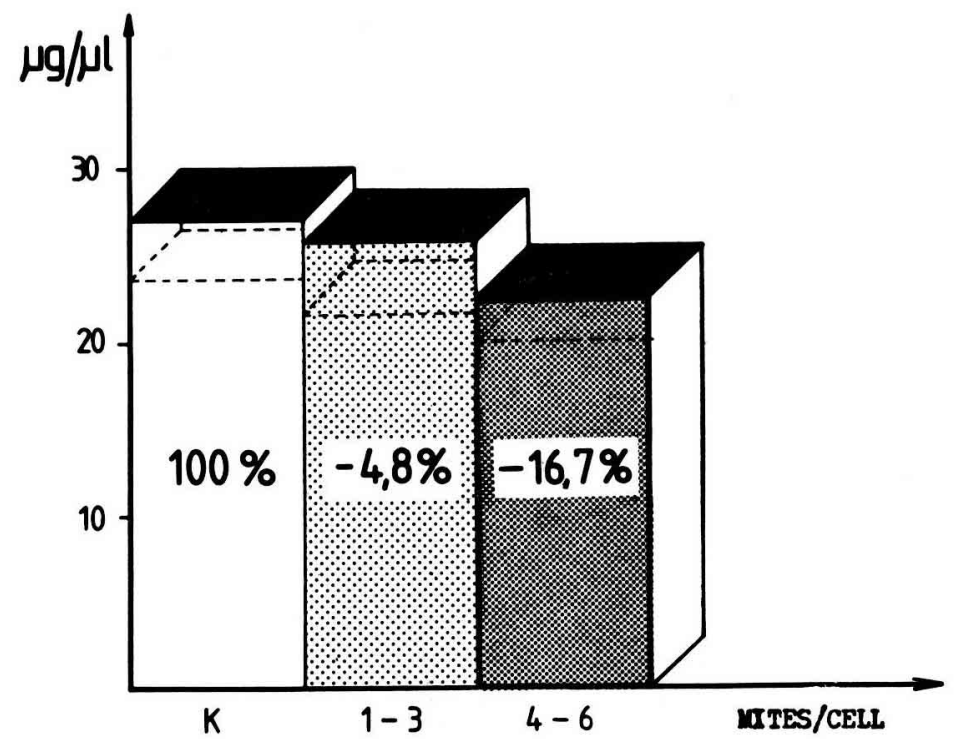

Fig. 2. - Protein concentration in the haemolymph $(\mu \mathrm{g} / \mu \mathrm{l})$ of woiker pupae with brown eyes in relation to the infestation rate

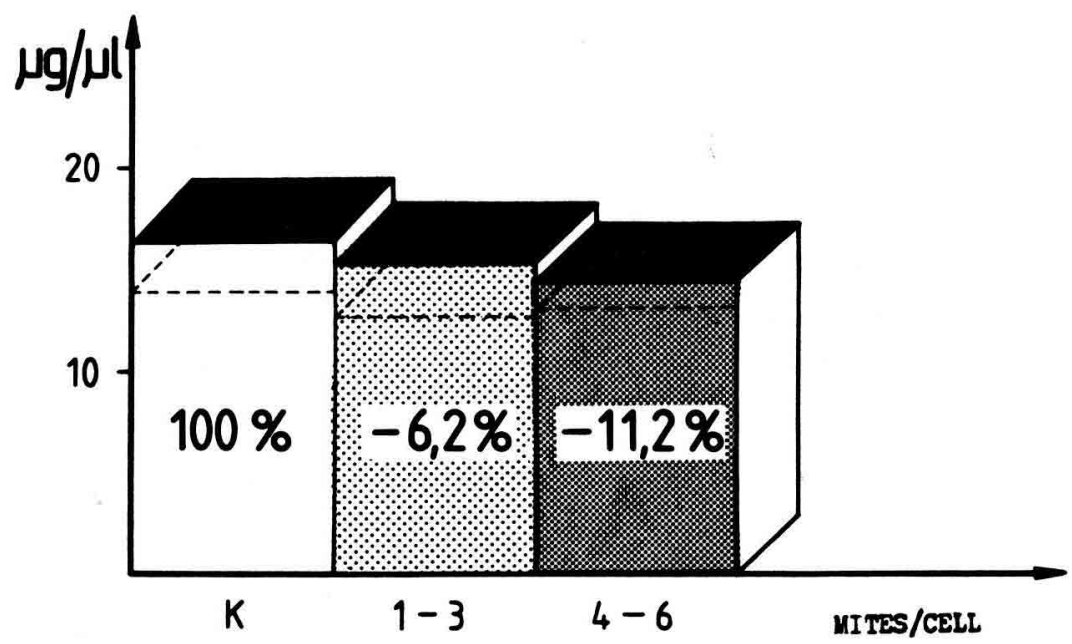

FIG. 3. - Protein concentration in the haemolymph $(\mu \mathrm{g} / \mu \mathrm{l})$ of worker bees in the pre-emerging stage in relation to the infestation rate

A significant difference referring to the control group could only be recognized at a parasitization of 4-6 mites/cell. 

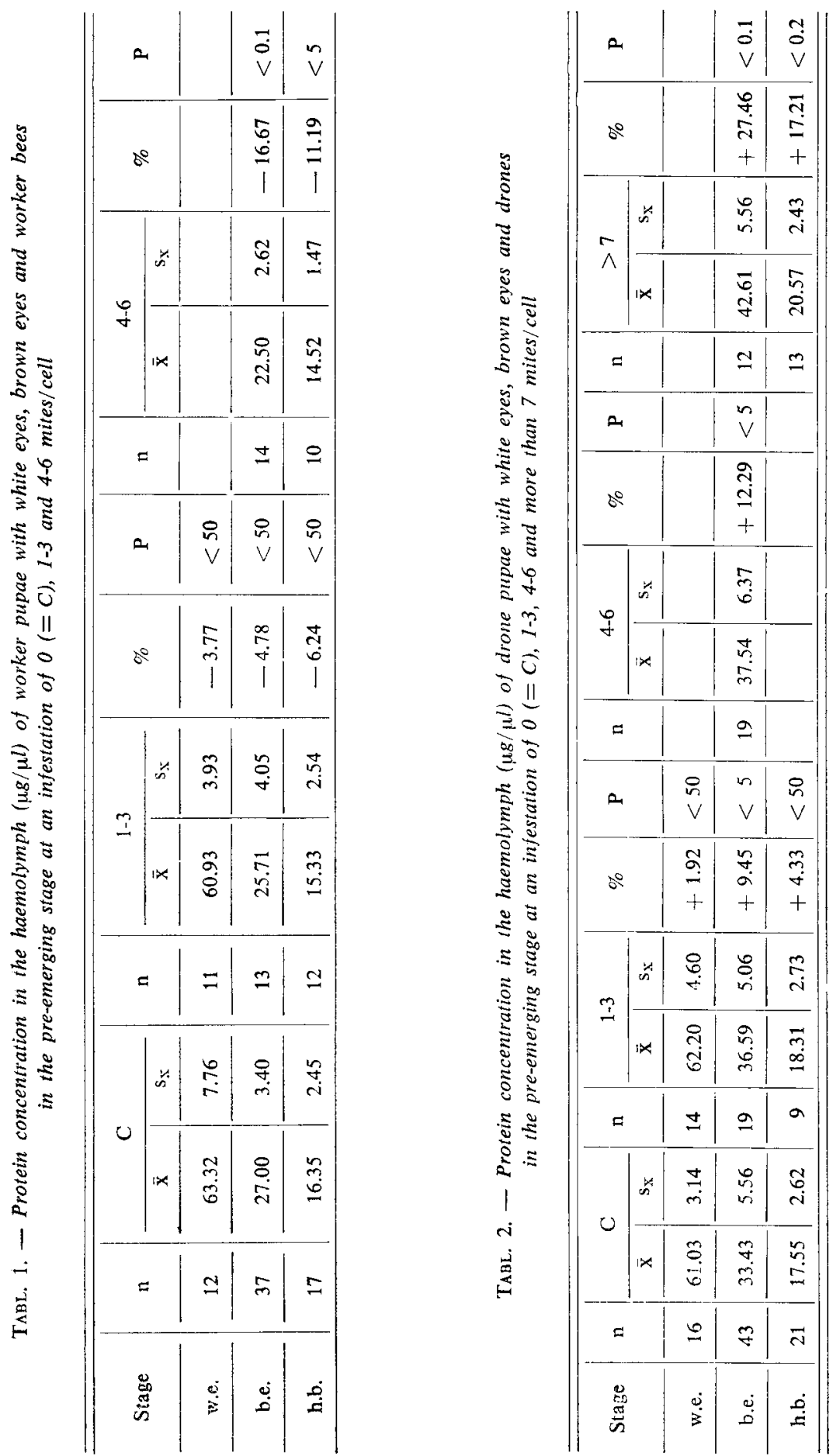
2. Protein concentration in the haemolymph of drone brood

The classification of the groups corresponded to the classification by the worker brood (w.e., b.e., h.b.). Concerning the intensity of parasitization it was possible to work with drone brood infested with more than 7 mites per cell.

Results are shown in Tabl. 2.

Contrary to the findings in the brood of the worker bees the protein concentration in the haemolymph of the drone brood and the rate of parasitization increased simultaneously. In the non-infected stage of pupae with white eyes, the average protein concentration was $61.03 \mu \mathrm{g} / \mathrm{kl}$ (Fig. 4).

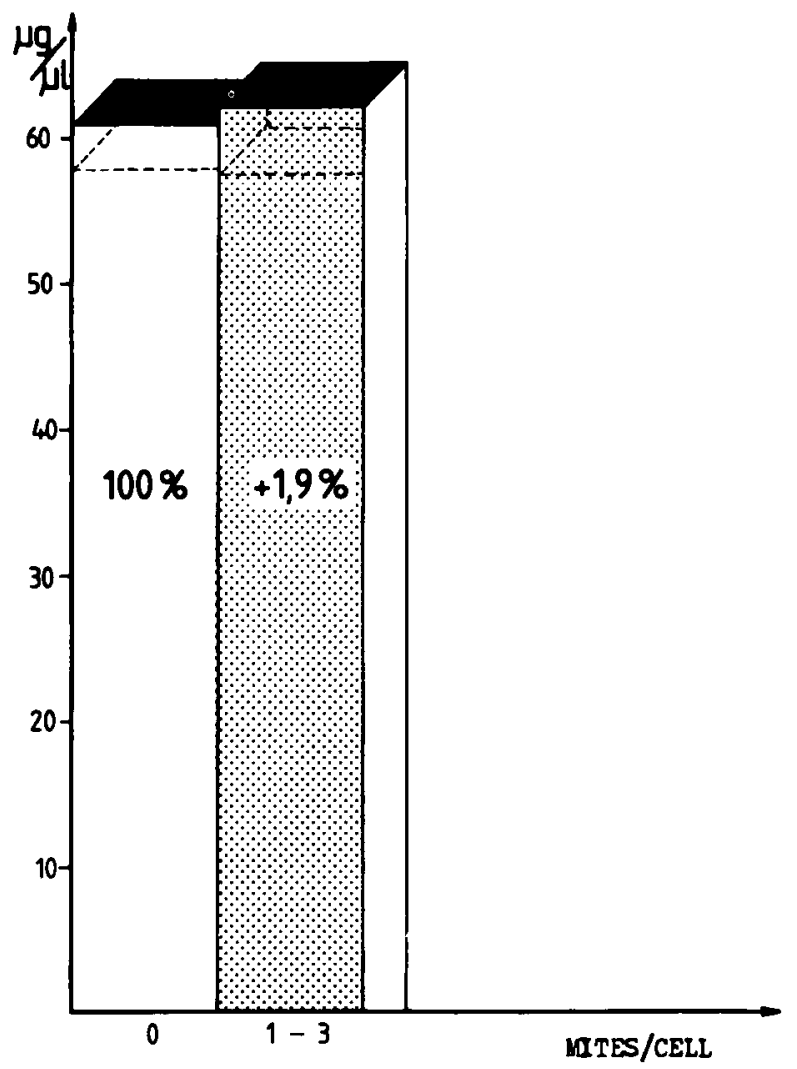

FIG. 4. - Protein concentration in the haemolymph $(\mu \mathrm{g} / \mu \mathrm{l}$, of drone pupae with white eyes in relation to the infestation rate

The measurements of the haemolymph samples of drone pupae with brown eyes, without mites, showed a protein concentration of $33.43 \% \mu \mathrm{g} / \mu \mathrm{l}$. This rose 
from $9.45 \%$ to $36.59 \mu \mathrm{g} / \mu \mathrm{l}$ with $1-3$ mites/cell and by $12.29 \%$ to $37.54 \mu \mathrm{g} / \mu \mathrm{l}$ with 4-6 mites/cell. The highest protein concentration was observed at an infestation of more than 7 mites/cell with an average value of $42.61 \mathrm{lg} / \mathrm{ll}$, showing an increase of $27.46 \%$ over the control group (Fig. 5).

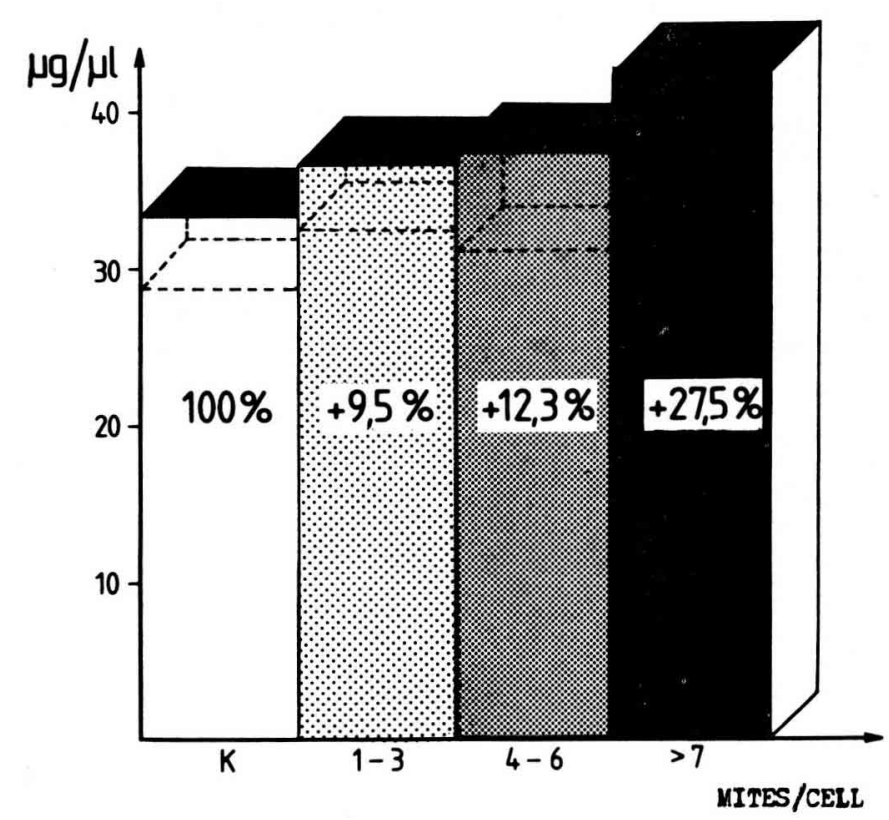

FIG. 5. - Protein concentration in the haemolymph $(\mu \mathrm{g} / \mu \mathrm{l})$ of drone pupae with brown eyes in relation to the infestation rate

In the control group the average protein concentration in the haemolymph of drones in the pre-emerging stage was $17.55 \mathrm{\mu g} / \mathrm{kl}$. An infestation of 1-3 mites led to an increase of $4.33 \%$ to $18.31 \mathrm{\mu g} / \mathrm{ll}$ and with more than $7 \mathrm{mites} / \mathrm{cell}$ from $17.21 \%$ to $20.57 \mu \mathrm{g} / \mu 1$ (Fig. 6).

The protein concentration of all groups differed significantly from the control group with the exception of two groups, pupae with white eyes and drones in the pre-emerging stage with an infestation rate of 1-3 mites/cell.

\section{Determination of the haemolymph volume of the brood of both castes}

Only one stage, pupae with brown eyes, was investigated with regard to the haemolymph volume. The experiments showed that an infestation with mites resulted in a diminution of the haemolymph volume in the female and male brood. 


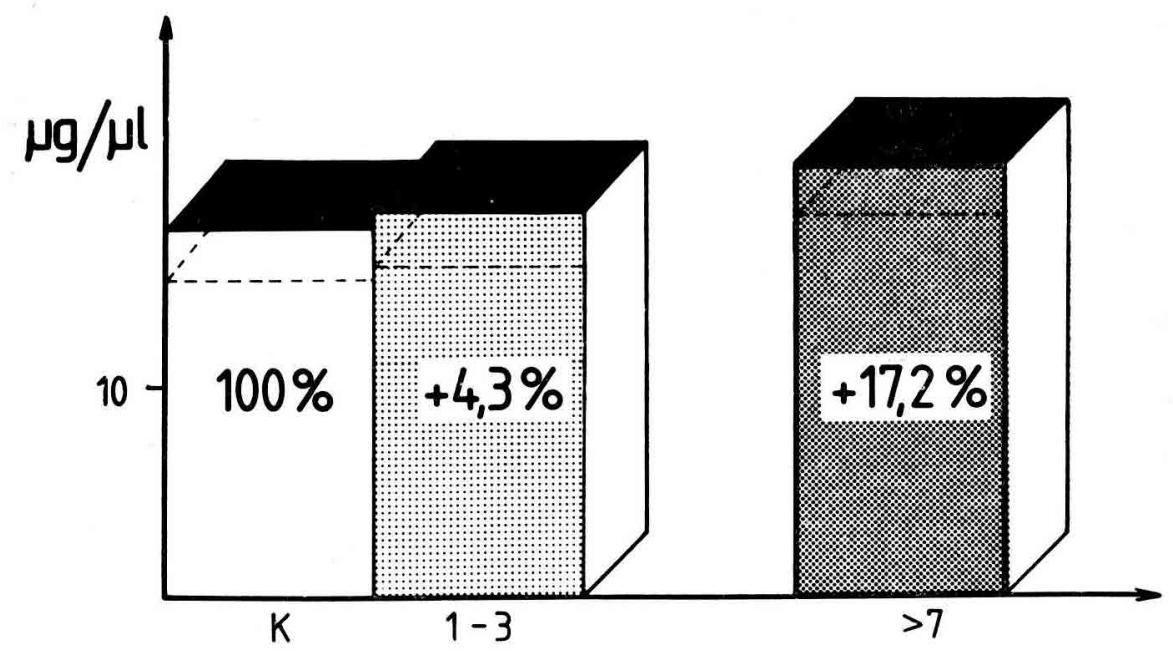

MITES/CELL

FIG. 6. - Protein concentration in the haemolymph $(\mu g / \mu l)$ of drones in the pre-emerging stage in relation to the infestation rate

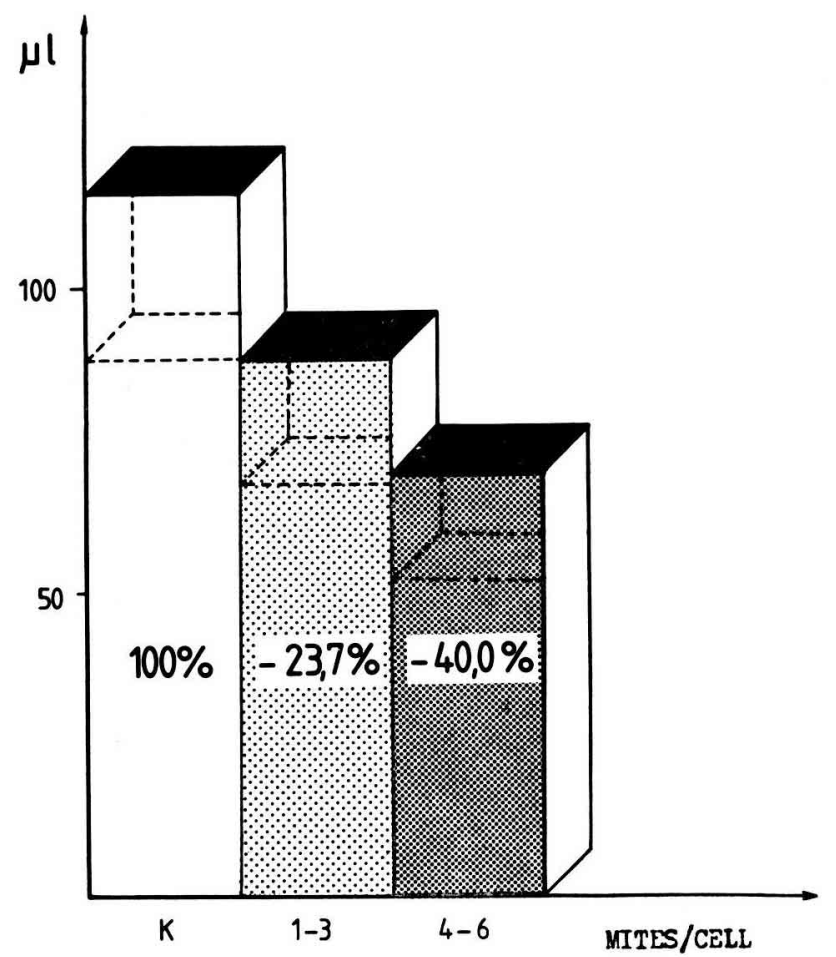

FIG. 7. - Haemolymph volume $(\mu l)$ in worker pupae with brown eyes in relation to the infestation rate 
A summary of the changes in the haemolymph volume in relation to the intensity of parasitization is presented in Tabl. 3.

Unparasitized worker pupae have an average volume of $115.56 \mu \mathrm{l}$. An infection of 1-3 mites diminished the haemolymph volume by $23.65 \%$ to $88.23 \mu 1$ and an infestation of $4-6$ mites by $40.01 \%$ to 69.32 pl (Fig. 7).

In both cases the differences from the control group were significant.

Similar to worker brood, the reduction in the haemolymph volume in drone brood proved to be dependent on the intensity of parasitization. The non-infested drone pupae had an average volume of 165.17 \&l. This volume showed decreases of $18.92 \%(133.92, \mathrm{ll})$ with $1-3 \mathrm{mites} / \mathrm{cell}$ and $21.92 \%(128.97 \quad \mathrm{ll})$ with 4-6 mites/cell. The greatest influence on the haemolymph volume was observed with more than 7 mites/cell. In this case the volume was reduced to $113.96 \mathrm{fl}$, a decrease of $31.00 \%$ (Fig. 8).

All the results differed significantly from the control group.

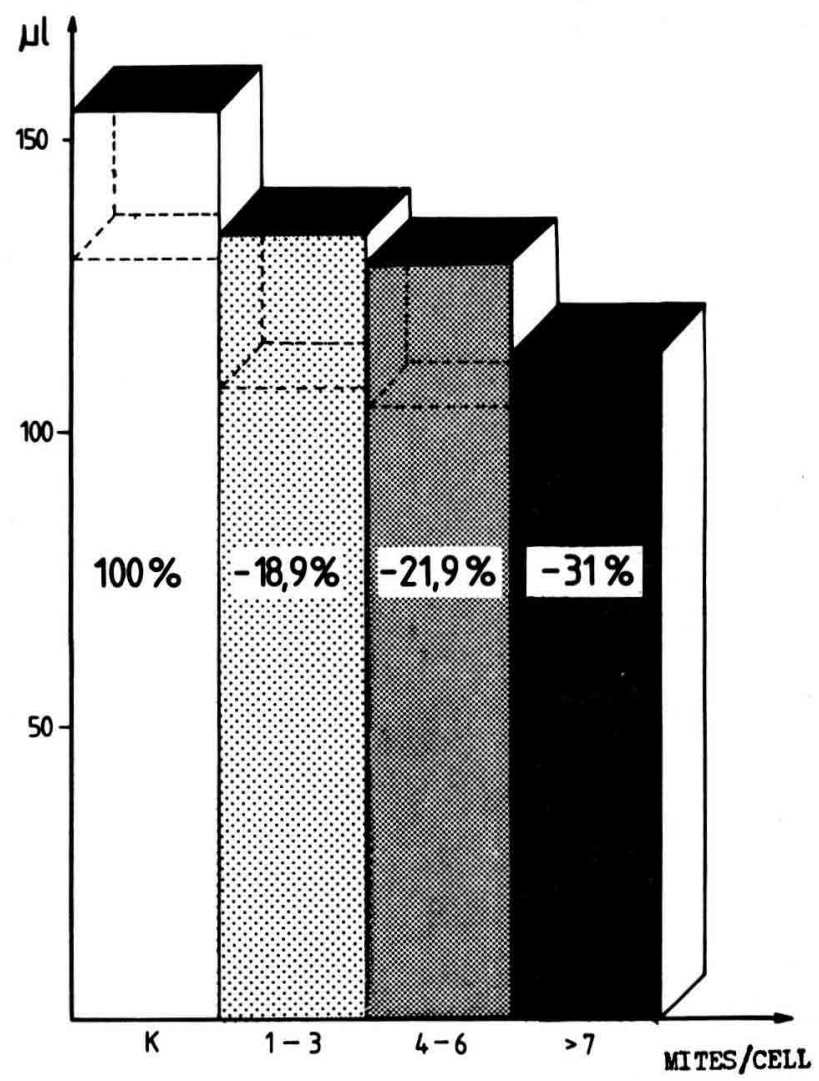

FIa. 8. - Haemolymph volume $(\mu l)$ in drone pupae with brown eyes in relation to the infestation rate 

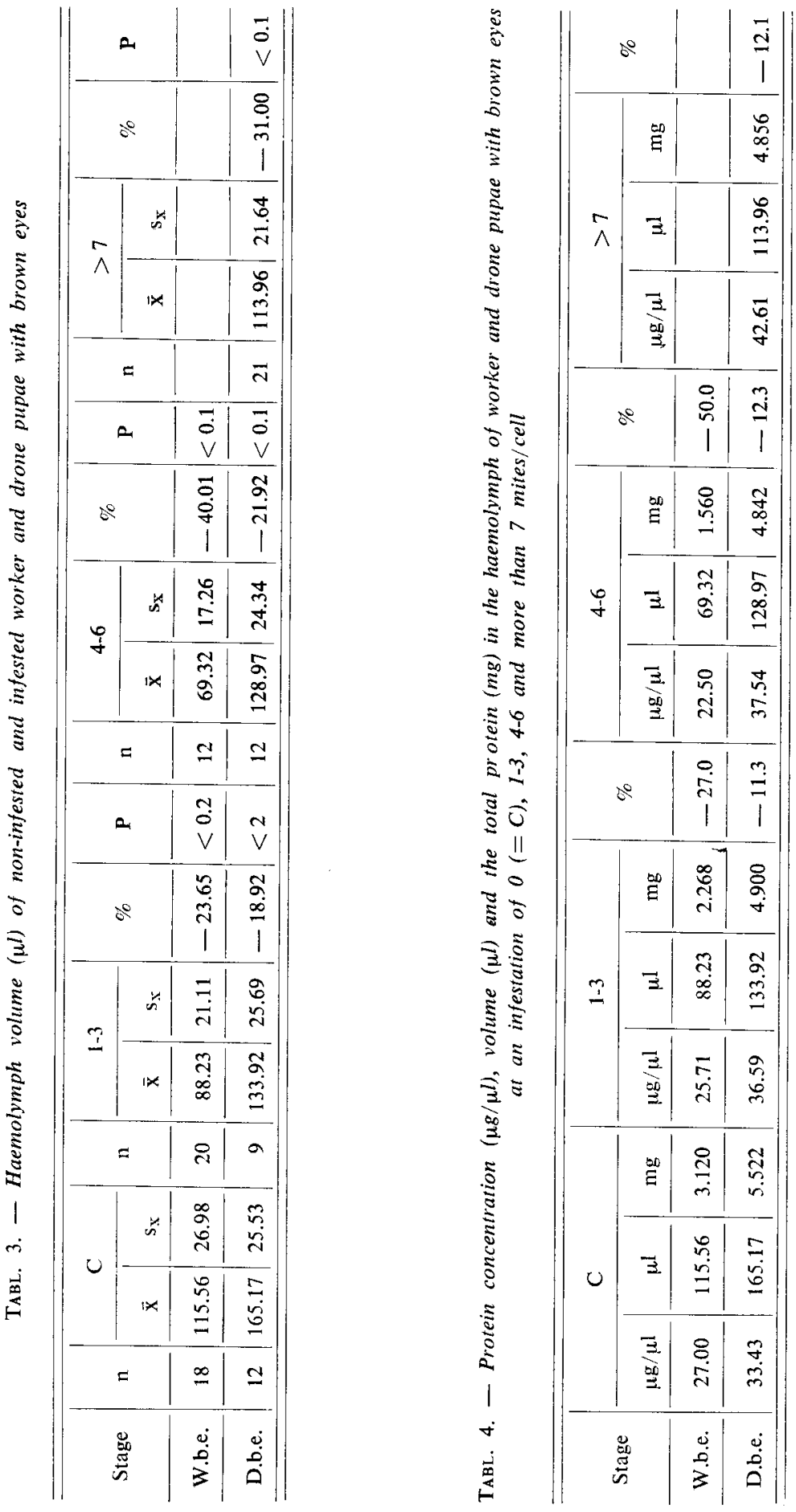


\section{The calculation of the absolute protein quantity}

By means of the average protein concentrations in the haemolymph and the average haemolymph volumes, it is possible to calculate the total protein in pupae with brown eyes in relation to the different parasitization rates.

The results are shown in Tabl. 4.

It is obvious that the parasitization by varroa-mites strongly influenced the total protein quantity in the haemolymph of worker pupae. An infestation of 1-3 mites caused a reduction of the protein content by $27.00 \%$. A parasitization intensity of 4-6 mites/cell diminished the protein content by $50.00 \%$.

The influence of mites on the drone brood protein quantity was not as great as that on the worker brood. The loss of proteins by sucking mites amounted to about $12.00 \%$. Of special interest is the fact that the diminution of the protein content in all the three infestation groups of drones was more or less equal.

An infestation rate of $1-3 \mathrm{mites} / \mathrm{cell}$ reduced the total protein content by $11.3 \%, 4-6$ mites/cell by $12.3 \%$ and more than 7 mites/cell by $12.1 \%$.

Fig. 9 shows the influence of the differing impact of varroa-infestation on the total protein quantity in the haemolymph of worker and drone pupae with brown eyes.

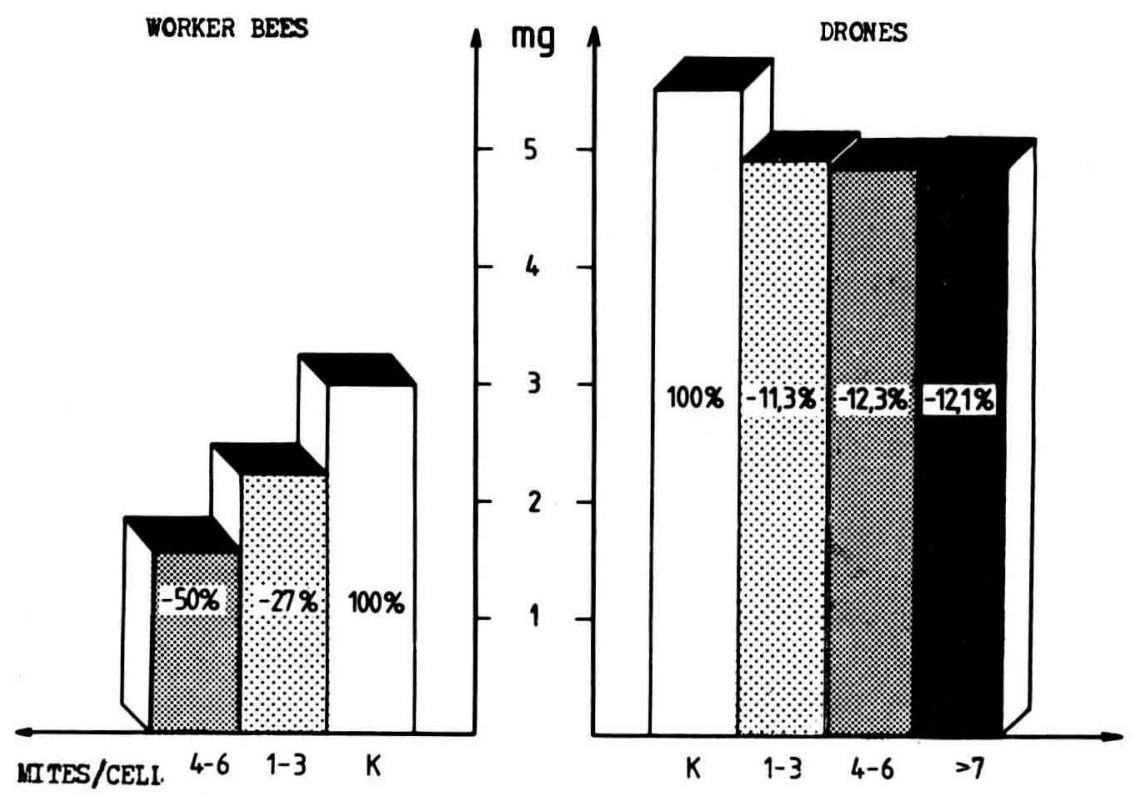

FIG. 9. - The total protein in the haemolymph (mg) of worker and drone pupae with brown eyes in relation to the infestation rate 


\section{DISCUSSION}

The results of the experiments showed, for the three stages of the worker brood that were studied, that the reductions in the protein concentration and the haemolymph volume depended on the number of feeding mites. The reduction in total protein in the haemolymph amounted to $27.0 \%$ when the infection rate was $1-3 \mathrm{mites} / \mathrm{cell}$ and $50.0 \%$ when the rate was $4-6 \mathrm{mites} / \mathrm{cell}$.

Weight-loss (Grobov, 1976 ; ChOI and Woo, 1974 ; De Jong et al., 1982) and shortening of lifespan (DE JONG and DE JoNG, 1983) appear to be governed by the intensity of the parasitization. This leads us to conclude that the reduction of the protein levels in the haemolymph may be one of the causes for the weightloss and shortening lifespan.

A comparison of our experimental results with other is only partly possible because of the lack of detailed information about the test conditions.

Only the results of Domazkaja (1980) allow a comparison. She discovered that from May-August newly emerged bees show a reduction in protein content from $39.2-51.5 \%$. She obtained this reduction from an infestation rate of 4 mites/cell. Our findings for pupae with brown eyes, 4-6 mites/cell, and for the same time period resulted in a $50 \%$ reduction in total protein.

The experiments with the drone brood led to different results. Only the reduction in haemolymph volume was correlated to the number of sucking mites which was similar to the results obtained for worker pupae. It was also observed that the protein concentration in the drone haemolymph (pupae) increased with an ascending number of mites.

The total protein in the drone haemolymph was indeed diminished by an infestation with mites, but the reduction showed no dependence on the intensity of the parasitization. The loss of proteins was always between 11.3-12.3\% compared to the control group. A parasitization of 1-3 mites/cell led to a protein content of $4.900 \mathrm{mg}$. With $4-6$ mites/cell the protein level was $4.842 \mathrm{mg}$ and with more than 7 mites/cell the total protein was $4.856 \mathrm{mg}$.

Only a theoretical explanation for these findings is possible. It may be possible that drone pupae are able to compensate for the loss of proteins. It is well-known that the development of the spermatocytes is completed during the pupal stage. The sexual products consist of high concentrations of proteins from which small amounts of proteins could be utilized without weakening the drone's vitality.

Moreover there is no danger to the queen that she will not receive enough sperms, because copulation takes place several times (F. RUTTNER, 1957). From 
a parasitological view point, the findings indicate a low damage to the drones. There is no question that the host-parasite reationship (Apis cerana - Varroa jacobsoni) has existed for a very long time. This is documented by the wellbalanced relationship between these two «partners». Obviously there is no great difference between the mite-drone relationship in comparing the western to the eastern honey bee. Therefore a similar reaction between «western drones » and « eastern drones» with regard to varroa-infections might be expected.

However considerable differences were observed in the relationship of Apis mellifera and Apis cerana workers to mites. This helps to explain the more damaging effects of Varroa jacobsoni on Apis mellifera workers.

Received for publication in July 1985. Accepted for publication in September 1985.

\section{ACKNOWLEDGEMENT}

We wish to thank the Ministerium für Ernährung, Landwirtschaft und Forsten des Landes Nordrheinwestfalen for financial assistance.

\section{RESUME}

INFLUENCE DE L'ACARIEN VARROA JACOBSONI OUD. SUR LA CONCENTRATION EN PROTÉINES ET LE VOLUME DE L'HEMOLYMPHE
DU COUVAIN DE MALES ET D'OUVRIERES D'ABEILLES (APIS MELLIFICA L.)

Une étude concernant la concentration en protéines de l'hémolymphe et le volume de l'hémolymphe en fonction du degré d'infestation a été entreprise sous l'angle des interactions hôte (Apis mellifica)-parasite (Varroa jacobsoni).

\section{Méthodes}

La concentration en protéines a été déterminée par photométrie selon la méthode de LOWRY et le volume de l'hémolymphe par la méthode de dilution à l'inuline-14C. Les données ainsi obtenues permettent de calculer la teneur globale en protéines de l'hémolymphe. On a étudié le couvain d'ouvrières et le couvain de mâles (nymphes aux yeux blancs - w.e. - nymphes aux yeux marrons - b.e. -, et abeilles sur le point d'éclore - h.b.). On a retenu comme autre critère de classification le degré d'infestation ( $1^{\text {er }}$ degré d'infestation : 1-3 acariens par cellule;

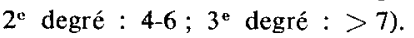

\section{Résultats}

1. Une infestation du $1^{\text {er }}$ degré conduit chez les nymphes d'ouvrières aux yeux blancs à une diminution de la concentration de $3,77 \%$ et chez les nymphes aux yeux marrons à une baisse de $4,78 \%$. Lorsque l'infestation est du $2^{e}$ degré, la baisse de concentration est de $16,67 \%$. Les abeilles sur le point d'éclore présentent une diminution de la concentration de $6,24 \%$ au $1^{\text {er }}$ degré d'infestation et de $11,19 \%$ au $2^{\text {e }}$ degré.

Chez les nymphes de mâles aux yeux blancs, la concentration en protéines augmente de $1,92 \%$ au $1^{\text {er }}$ degré d'infestation; au stade suivant (nymphes aux yeux marrons), l'augmentation est de $9,45 \%$ pour le $1^{\text {er }}$ degré d'infestation, de $12,29 \%$ pour le $2^{\text {e }}$ degré et de $27,46 \%$ pour le $3^{\text {e }}$ degré. Les mâles sur le point d'éclore présentent une augmentation de la concentration de $4,33 \%$ au $1^{\text {er }}$ degré d'infestation et de $17,21 \%$ au $3^{\text {e }}$ degré. 
2. Les mesures du volume de l'hémolymphe chez les nymphes aux yeux marrons des deux castes montrent que : chez les nymphes d'ouvrières, le volume de l'hémolymphe chute de $23,65 \%$ au $1^{\text {er }}$ degré d'infestation et de $40,01 \%$ au $2^{\circ}$ degré ; chez les nymphes de mâles, le volume diminue de $18,92 \%$ au $1^{\text {er }}$ degré d'infestation, de $21,92 \%$ au $2^{\text {e }}$ degré et de $31,00 \%$ au $3^{\text {e }}$ degré.

3. A partir de ces données on peut calculer pour les nymphes d'ouvrières aux yeux marrons une perte globale en protéines de $27 \%$ au $1^{\text {er }}$ degré d'infestation et de $50 \%$ au $2^{\text {e }}$ degré. Chez les nymphes de mâles du même stade, on a également enregistré une perte en protéines, mais elle n'est pas aussi forte et n'est pas corrélée avec le degré d'infestation, comme le montrent les données suivantes. Le $1^{\mathrm{er}}$ degré d'infestation induit une diminution des protéines de $11,3 \%$, le $2^{\text {e }}$ degré une diminution de $12,3 \%$ et le $3^{\text {* }}$ degré une diminution de $12,1 \%$.

\section{Discussion}

On trouve dans la bibliographie des données selon lesquelles perte de poids et raccourcissement de la durée de vie provoqués par Varroa sont corrélés chez les ouvrières avec le degré d'infestation. Cela nous permet de conclure que la réduction de la teneur en protéines peut être l'une des causes de ces perturbations physiologiques. Chez les nymphes de mâles par contre, on n'a pas pu établir de relation entre la perte globale en protéines et le degré d'infestation. Il est possible que les nymphes de mâles soient capables de compenser la perte en protéines (éventuellement par une production moindre des substances sexuelles).

D'un point de vue parasitologique, ceci indique une relation hôte-parasite plus ou moins bien équilibrée entre les nymphes de mâles d'Apis mellifica et Varroa jacobsoni, semblable à celle qui existe entre Apis cerana et ce même acarien.

\section{ZUSAMMENF ASSUNG}

\section{DER EINFLUSS DER MILBE VARROA JACOBSONI OUD. AUF DIE PROTEINKONZENTRATIONEN UND DIE HAMOLYMPHVOLUMINA VON ARBEITERINNEN- UND DROHNENBRUT DER HONIGBIENE APIS MELLIFERA L.}

Unter dem Aspekt der Wechselbeziehungen zwischen dem Wirt Apis mellifera und dem Parasit Varroa jacobsoni wurden Untersuchungen über die Proteinkonzentrationen in der Hämolymphe und die Hämolymphvolumina in Abhängigkeit von der Befallsstärke durchgeführt.

Die Konzentrationsmessungen erfolgten photometrisch nach LOWRY, die Bestimmungen der Hämolymphvolumina mittels der $14 \mathrm{C}$-Inulin-Verdünnungsmethode. Anhand der so erhaltenen Daten konnte der Gesamptproteingehalt der Hämolymphe berechnet werden. Untersucht wurde sowohl Arbeiterinnen- als auch Drohnenbrut (Puppen mit weißen Augen - w.e. -, Puppen mit braunen Augen - b.e. - und schlupfbereite Bienen - h.b. -). Ein weiteres Klassifizierungsmerkmal war die unterschiedliche Befallsstärke (1-3, 4-6 und mehr als 7 Milben/Zelle).

Die Untersuchungen ergaben folgende Befunde :

1. Ein Befall von 1-3 Milben/Zelle führte bei Arbeiterinnenpuppen mit weißen Augen zu einer Konzentrationsminderung von 3,77\%. Ein gleich starker Befall von Puppen mit braunen Augen bewirkte eine Abnahme von 4,78\% und bei 4-6 Milben von 16,67\%. Schlupfbereite Arbeiterinnen erlitten bei einem Befall von 1-3 Milben einen Konzentrationsverlust von 6,24\% und bei 4-6 Milben von $11,19 \%$.

Bei Drohnenpuppen mit weißen Augen erhöhte sich die Proteinkonzentration bei einem Befall von 1-3 Milben um 1,92\%; beim nächst älteren Stadium, Puppen mit braunen Augen, stieg die -Proteinkonzentration um 9,45\% bei einem Befall von 1-3 Milben und um 12,29\% bei 4-6 Milben und bei mehr als 7 Milben um 27,46\%. Für die schlupfbereiten Drohnen ergab sich bei 1-3 Milben eine Konzentrationserhöhung um 4,33\% und bei mehr als 7 Milben um $17,21 \%$.

2. Die Hämolymphvolumina-Messungen ergaben für Puppen mit braunen Augen (beide Kasten) folgende Ergebnisse : 
Bei Arbeiterinnenpuppen sank das Hämolymphvolumen bei einem Befall von 1-3 Milben um 23,65\% und bei 4-6 Milben um 40,01\%.

Bei den Drohnenpuppen nahm das Hämolymphvolumen bei 1-3 Milben um 18,92\%, bei 4-6 Milben um 21,92\% und bei mehr als 7 Milben um 31,00\% ab.

3. Aus diesen Daten konnte für die Arbeiterinnenpuppen mit braunen Augen bei einem Befall von 1-3 Milben ein Gesamtproteinverlust von $27 \%$ und bei 4-6 Milben von $50 \%$ berechnet werden.

Bei den Drohnenpuppen mit braunen Augen wurde ebenfalls ein Verlust von Proteinen registriet. Er ist aber nicht so gravierend und auch nicht mit der Befallsstärke korreliert, wie die nachfolgenden Daten belegen. Ein Befall von 1-3 Milben bewirkte eine Proteinminderung von 11,3\%, von 4-6 Milben von $12,3 \%$ und von mehr als 7 Milben von $12,1 \%$.

In der Literatur finden sich Angaben, daß die durch den Varroa-Befall bewirkten Gewichtsverluste und Lebenszeitverkürzungen bei Arbeiterinnen mit der Befallsstärke korreliert sind. Diese Befunde lassen den berechtigten Schluß zu, daß eine mögliche Ursache für diese Schadbilder der Proteinverlust ist.

Bei Drohnenpuppen war eine solche Abhängigkeit des Verlustes der Gesamtproteinmenge von der Befallsstärke nicht festzustellen. Möglicherweise vermögen Drohnenpuppen den Verlust an Proteinen weitgehend zu kompensieren (evtl. durch eine verminderte Produktion von Geschlechtsprodukten).

Von parasitologischer Sicht her würde dies für ein mehr oder minder gut ausgewogenes WirtParasit-Verhältnis zwischen den Drohnenpuppen von Apis mellifera und Varroa jacobsoni sprechen, ähnlich dem zwischen Apis cerana und dieser Milbe.

\section{REFERENCES}

CHol S.Y., Woo K.S., 1974. - Studies on the bionomics of the bee mite Varroa jacobsoni Oudemans and its chemical control. Resp. Rep. Off. Rural Dev. Stoweon, Korea, 16 (Livestock), 69-76.

DE Jong D., De Jong F'.H., Goncalves L.S., 1982. - - Weight loss and other damage to developing worker honeybees from infestation with Varroa jacobsoni. J. Apic. Res., 21 (3), 165-167.

DE Jong D., DE Jong P.H., 1983. — Longevity of africanized honey bees (Hymenoptera : Apidae) infested by Varroa jacobsoni (Parasitiformes : Varroidae). J. Econ. Entomol., 76 (4), 766-768.

Domazkaja T.F., 1980. - Anzeichen in der Bienenhämolymphe bei Varroatose (in russisch). Veterinarija, 11, 47.

Grobov O.F., 1976. - Varroasis in bees. Apimondia, 46-91.

LEVENBOoK L., 1958. - Intracellular water of larval tissues of the southern armyworm as determined by the use of 14C-carboxylin-inulin. J. Cell. Comp. Physiol., 52, 329-340.

Lowry D.H., Rosebrough N.J., Farr A.L., Randall R.J., 1951. - Protein measurement with the Folin phenol reagent. J. Biol. Chem., 193, 248-254.

Ruttner F., 1957. - Aktuelle Probleme auf dem Gebiet der Fortpflanzung und Züchtungsforschung der Biene. Disch. Bienenwirtsch., 8, 41, 81, 189. 